\title{
Survei Sero Epidemiologik Infeksi Helicobacter pylori pada Siswa Sekolah Dasar Negeri Jebres Surakarta dengan Metoda PHA
}

\author{
B.Subagyo
}

Latar belakang. Infeksi $H$. pylori ditandai dengan ditemukan IgG anti $H$. pylori. Sebagian infeksi $H$. pylori tidak memberikan gejala klinik dan merupakan penyebab gastritis kronik dan karsinogenik lambung. Sampai saat ini kemampuan untuk mendiagnosis infeksi $H$. pylori masih terbatas.

Tujuan. Untuk mengetahui prevalensi infeksi H. pylori pada siswa Sekolah Dasar Negeri Jebres, umur 6-14 tahun di Surakarta.

Metoda. Penelitian ini dilakukan secara studi potong lintang, analitik. Infeksi $H$. pylori berdasarkan hasil pemeriksaan serologi PHA yang dibuat dari antigen lokal. Populasi pada penelitian ini adalah siswa Sekolah Dasar Negeri di Jebres Surakarta, dengan kondisi sosial ekonomi yang rendah. Sampel adalah siswa sekolah yang diijinkan orangtuanya mengikuti penelitian ini, dengan menandatangani informed consent.

Hasil. Prevalensi infeksi $H$. pylori didapatkan 107 PHA positip pada 532 siswa (20,1\%); siswa perempuan $27.3 \%$ dari 205 siswa sedangkan pada laki-laki $12.0 \%$ dari 220 siswa. Kelompok umur 6-9 tahun dijumpai PHA positip 13.0\% dari 241 siswa. Kelompok umur 10-14 tahun PHA positif $28.0 \%$ dari 184 siswa.

Kesimpulan. Prevalensi pada siswa perempuan lebih tinggi dari pada siswa laki-laki Prevalensi kelompok umur 10-14 tahun lebih tinggi dari kelompok siswa umur 6-9 tahun. Tingginya prevalensi infeksi $H$. pylori mungkin sebagai akibat higiene dan sanitasi lingkungan yang buruk. Pemeriksaan serologi poliklonal metoda PHA, dibuat dari antigen lokal dan perlu dikembangkan lebih baik dari sisi harga, produksi maupun pendistribusiannya.

Kata kunci: Helicobacter pylori, siswa sekolah dasar, serologi-PHA.

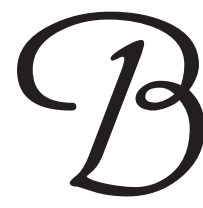

eberapa hasil penelitian epidemiologis menunjukkan bahwa prevalensi infeksi H. pylori di negara industri rendah, sebaliknya di negara berkembang cukup

\footnotetext{
Alamat korespondensi:

Dr. B. Subagyo, SpA.

SMF Penyakit Anak RS. Dr. Muwardi/ Lab.IKA FK UNS Surakarta

Alamat rumah: J1.Prof Dr. Supomo no 119. Surakarta (57132)

Telepon: (0271) 728123, Fax: (0271)-664598
}

tinggi. ${ }^{1}$ Infeksi $H$. pylori di negara yang sedang berkembang sudah dimulai pada umur muda bahkan pada bayi. ${ }^{2}$

Deklarasi WHO menyatakan bahwa infeksi $H$. pylori dapat sebagai karsinogen pada lambung. Infeksi $H$. pylori yang berlangsung dalam jangka waktu beberapa puluh tahun akan mengalami perubahan menjadi gastritis kronik yang selanjutnya sebagian dari gastritis tersebut akan berubah menjadi kanker lambung. Secara teoritis dapat terjadi cara penularan bakteri $H$. pylori secara oral-oral, maupun gastrik-oral. ${ }^{3}$ 
Terdapat dua cara untuk menegakkan diagnosis infeksi $H$. pylori. Pertama, dengan cara invasif yaitu menggunakan alat endoskop. Dengan endoskop dapat dilakukan biopsi pada mukosa gaster, untuk selanjutnya dilakukan pemeriksaan histopatologi maupun kultur. Pemeriksaan dengan CLO (campylobacter like organism) yaitu merupakan pemeriksaan cepat untuk mendeteksi adanya urease yang dihasilkan kuman H.pylori. Dengan menggunakan tablet agar yang mengandung ureum, tablet tersebut akan berubah warnanya pada keadaan $\mathrm{pH}$ yang meningkat oleh karena kuman $H$. pylori. Pemeriksaan DNA dapat juga untuk mendiagnosis infeksi $H$. pylori. Pemeriksaan kedua adalah pemeriksaan noninvasif, seperti pemeriksaan $C$ urea breath test dan pemeriksaan serologi yaitu untuk mendeteksi antibodi $\operatorname{Ig} G$ anti $H$. pylori di dalam darah pengidap. Pada prinsipnya kuman $H$. pylori yang hidup di permukaan mukosa, akan menghasilkan antigen yang menimbulkan respon imun dengan terbentuknya $\lg G$ anti $H$. pylori. Dikenal dua jenis imunoglobulin anti $H$ pylori, pertama IgM yang berlangsung singkat kurang dari 6 bulan, kemudian disusul $\operatorname{Ig} G$ anti $H$. pylori yang dapat dideteksi lebih dari 6 bulan sejak bakteri masuk ke dalam tubuh. Antigen yang dipakai adalah whole cell atau fragmen bakteri $H$ pylori. ${ }^{4,5}$

Laboratorium Biomedis RSU Mataram di Lombok, berhasil membuat antigen yang berasal dari beberapa strain bakteri $H$. pylori lokal. Penelitian Harijono. $\mathrm{A}^{6} \mathrm{di}$ RSUD Saiful Anwar Malang, dengan uji PHA dari laboratorium Biomedis tersebut menunjukkan sensitifitas $85,1 \%$ dan spesifisitas $95,5 \% .^{6}$

\section{Bahan dan Cara}

Penelitian dilakukan pada tahun 1997 dengan menggunakan metoda potong lintang (cross sectional) dan analisis kai kuadrat untuk mengetahui apakah ada perbedaan pengidap infeksi $H$. pylori menurut jenis kelamin dan kelompok umur siswa. Populasi penelitian adalah siswa sekolah Sekolah Dasar di Jebres, kota Surakarta. Sampel adalah anak Sekolah Dasar Jebres yang bersedia mengikuti penelitian ini. Orang tua yang mengijinkan anaknya mengikuti penelitian ini diminta untuk menandatangani informed consent.

Darah sebanyak $3 \mathrm{ml}$ diambil serumnya kemudian disimpan pada suhu $2-4^{\circ} \mathrm{C}$. Setelah darah terkumpul, dikirim ke Laboratorium Unit Riset Biomedik RSU
Mataram dengan menggunakan termos berisi es pada suhu $2-4^{\circ} \mathrm{C}$ dan dikirim dalam waktu kurang dari 2 jam. Sebelum diperiksa serum disimpan pada suhu 2$4^{\circ} \mathrm{C}$, selanjutnya dilakukan pemeriksaan dengan metoda PHA.

\section{Hasil}

Dari Tabel 1 dapat dilihat jumlah sampel yang mengikuti penelitian 532 siswa, terdiri dari laki-laki 250 dan 282 perempuan. Jumlah anti $H$. pylori positip ditemukan pada 107 siswa yang terdiri dari siswa lakilaki $30(12,0 \%)$ dan $77(27,3 \%)$ pada siswa perempuan. Dengan analisis kai kuadrat, didapatkan hasil $\mathrm{p}<0,05$.

Perhitungan $\mathrm{p}<0,05$, menunjukkan ada perbedaan yang bermakna antara jumlah anak pengidap infeksi $H$. pylori antara laki-laki dengan perempuan

Tabel 1. Frekuensi distribusi PHA IgG anti H. pylori menurut jenis kelamin siswa

\begin{tabular}{lccc}
\hline Jenis kelamin & \multicolumn{2}{c}{ Anti H pylori } & Jumlah \\
\cline { 2 - 3 } & Positip (\%) & Negatif (\%) & \\
\hline Laki-laki & $30(12,0)$ & $220(88,0)$ & 250 \\
Perempuan & $77(27,3)$ & $205(72,7)$ & 282 \\
\hline Jumlah & $107(20,1)$ & $425(79,9)$ & 532 \\
\hline p $<0,05$ & & &
\end{tabular}

Tabel 2 Menunjukkan anti $H$. pylori positip pada kelompok umur 6-9 tahun, ditemukan pada 36 anak $(13,0 \%)$, pada kelompok umur 10-14 tahun sebanyak 71 siswa $(28,0 \%)$. Terdapat perbedaan yang bermakna antara kedua kelompok. Tampaknya terdapat kecenderungan semakin bertambah umur, anti $H$. pylori positip semakin meningkat. Pada analisis kai kuadrat didapatkan $\mathrm{p}<0,05$.

Tabel 2. Frekuensi PHA anti $H$. pylori positip menurut kelompok umur siswa

\begin{tabular}{lccc}
\hline Kelompok & \multicolumn{2}{c}{ Anti H pylori } & Jumlah \\
\cline { 2 - 4 } Umur siswa & Pos $(\%)$ & Neg $(\%)$ & \\
\hline 6-9 th & $36(13,0)$ & $241(87,0)$ & 277 \\
10-14 th & $71(28,0)$ & $184(72,0)$ & 255 \\
\hline Jumlah & $107(20,1)$ & $425(79,9)$ & 532 \\
\hline p $<0,05$ & & &
\end{tabular}


Sari Pediatri, Vol. 7, No. 3, Desember 2005

\section{Diskusi}

Bakteri $H$. pylori pada manusia menyebabkan infeksi yang akan berlangsung seumur hidup kecuali apabila mendapat terapi eradikasi. Infeksi $H$. pylori dalam jangka waktu puluhan tahun dapat menyebabkan gastritis kronik, dan sebagian gastritis kronik ini dapat berubah menjadi kanker gaster. Infeksi $H$. pylori pada umumnya tidak memberi gejala klinik

Hasil penelitian ini menunjukkan bahwa prevalensi kelompok H.pylori umur 6-9 tahun $13,0 \%$ dan kelompok umur 10-14 tahun adalah 28,0\%, berarti prevalensi infeksi $H$. pylori tersebut cukup tinggi. Hal ini kemungkinan sebagai akibat perbedaan asal dan kondisi sosioekonomi.

Penelitian yang dilakukan Suparyatmo ${ }^{2}$ juga menggunakan metoda PHA, pada pasien yang berobat di RSUD DR Muwardi Solo menunjukkan prevalensi infeksi $H$. pylori sebesar 7,2\% dari 963 anak berumur 0-14 tahun. Kelompok anak laki-laki infeksi $H$. pylori positip 34 (7,5\%), anak perempuan 35 positip (6,9\%). Kelompok umur 5-9 tahun prevalensi anti $H$. pylori 3,7\% dari 187 anak, sedangkan pada kelompok umur 10-14 tahun, sebesar $12 \%$ atau 26 anak dari 190 anak. Suparyatmo mengambil populasi dari rumah sakit, dengan kondisi sosial yang beragam.

Penelitian Kandera ${ }^{7}$ dengan metoda PHA di Sekolah Dasar di Bali, menunjukkan infeksi $H$. pylori positif pada kelompok umur 6 tahun $(17,4 \%)$, umur 7 tahun $(29,1 \%)$, umur 8 tahun dari 44 siswa $(25,6 \%)$, umur 9 tahun $(8,1 \%)$, dan umur 10 tahun 3,5\%. Dilihat dari jenis kelamin pengidap infeksi $H$. pylori siswa perempuan 76 anak (44,2\%), dan siswa laki-laki 96 anak (55,8\%).

Dari ketiga penelitian tersebut didapatkan hasil, antara pengidap infeksi $H$. pylori pada anak tidak terlalu tinggi, sedangkan menurut jenis kelamin tidak menunjukkan perbedaan yang konsisten. Pada usia sekolah anak perempuan lebih rawan terhadap risiko infeksi $H$. pylori. Risiko infeksi pada anak perempuan meningkat kemungkinan karena anak perempuan sudah dapat mengganti peran ibu seperti mencuci pakaian kotor atau mencuci sayuran. Secara keseluruhan, prevalensi infeksi $H$. pylori meningkat dengan meningkatnya umur, hal ini dapat dijelaskan bahwa anak yang lebih tua akan mendapat paparan bakteri $H$. pylori yang lebih lama artinya mendapatkan risiko terinfeksi $H$. pylori lebih besar. Infeksi dapat berasal dari lingkungan keluarga, akan tetapi kemungkinan sumber infeksi yang berasal dari higiene dan kesehatan lingkungan yang buruk, merupakan pola infeksi di negara miskin.

Prevalensi infeksi $H$. pylori dengan pemeriksaan $C$ urea breath test, di Jerman menunjukkan prevalensi yang rendah. Rothenbacher melaporkan, pada anak prasekolah pada etnik Jerman, infeksi $H$. pylori positif 4,9\% sedangkan etnik Turki 44,1\%, dan imigran lainnya $22,7 \%$. Pada semua etnik, infeksi $H$. pylori positip sebesar $11.3 \% .{ }^{8}$ Pada penelitian ini disimpulkan bahwa etnik asal imigran berasal dari negara yang sedang berkembang menunjukkan prevalensi infeksi $H$. pylori tinggi, kemungkinan sebelum imigrasi ke Jerman ibu atau ayahnya telah mengidap infeksi $H$. pylori. Di negara industri, dengan kebersihan lingkungan yang baik, kecil kemungkinan peran lingkungan sebagai sumber infeksi bakteri $H$. pylori seperti yang dilaporkan oleh Marshall. ${ }^{1}$

Penelitian Roekiandari ${ }^{9}$ di Surabaya, menunjukkan bahwa kuman $H$. pylori dapat hidup di air PAM dan air tanah selama lebih dari 6 hari. Gold ${ }^{10}$ melaporkan bahwa kuman $H$. pylori dapat hidup di air tanpa klor lebih dari 3 minggu. Dengan demikian negara yang sedang berkembang, dengan higiene dan sanitasi yang buruk merupakan sumber bakteri $H$ pylori. Selain air minum yang tercemar bakteri $H$. pylori sumber infeksi bakteri $H$. pylori dapat berasal dari air sungai, air tanah yang tercemar, jamban yang tidak kedap air, bahkan terdapat bukti bahwa air PAM di Surakarta juga tercemar bakteri $H$. pylori. ${ }^{11}$

Penelitian adanya kuman di rongga mulut yang berasal dari muntahan pengidap gastritis sudah lama diketahui. Peran anggota keluarga pengidap sebagai sumber infreksi $H$. pylori dikemukakan oleh beberapa peneliti. ${ }^{8,12,13}$ Di Indonesia khususnya di daerah rural, masih dijumpai budaya meloloh, yaitu suatu kebiasaan ibu mengunyah makanan hingga halus yang kemudian disuapkan pada bayi, kebiasaan ini dapat sebagai sumber penularan bakteri $H$. pylori. Cara lain penularan bakteri $H$. pylori adalah muntahan yang mengandung bakteri $H$. pylori kepada orang sehat disekitarnya. Kejadian penularan kuman $H$. pylori ini berlangsung pada usia muda.

Diagnosis infeksi $H$. pylori merupakan hal yang penting baik yang invasif maupun noninvasif. Di Indonesia sarana diagnostik masih terbatas dan pemeriksaan serologi khususnya ELISA cukup mahal. Hasil penelitian Harijono ${ }^{6}$ di RSU Malang, menunjukkan uji diagnostik pemeriksaan ELISA dengan baku emas yaitu biakan, diperoleh hasil sensitifitas $8,5 \%$ dan spesifisitas $91 \%$. 
Pemeriksaan lain yaitu dengan pemeriksaan antibodi terhadap $H$. pylori dikerjakan dengan metoda PHA, dengan menggunakan kit Bio-Medis anti $H$. pylori buatan Unit Riset Biomedik RSU Mataram. Menggunakan sel darah merah manusia golongan $\mathrm{O}$, yang diawetkan dengan glutaraldehid dan disensitisasi dengan larutan tanic acid akan terjadi proses aglutinasi yang dapat diamati secara makroskopik.

\section{Kesimpulan}

Prevalensi infeksi H. pylori pada para siswa Sekolah Dasar Jebres termasuk tinggi, sesuai dengan prevalensi infeksi $H$. pylori di negara yang sedang berkembang. Kemungkinan besar penularan infeksi $H$. pylori secara feco-oral berasal dari higiene dan sanitasi lingkungan yang buruk, termasuk air minum yang terkontaminasi bakteri, meskipun masih dimungkinkan penularan secara oral-oral.

Sarana diagnostik merupakan masalah yang penting. Kit PHA merupakan salah satu alternatif diagnostik infeksi $H$. pylori yang murah dengan sensitifitas dan spesifitas tinggi, perlu dikembangkan untuk diproduksi secara komersial.

\section{Ucapan terimakasih}

Kepada Prof. DR. Soewignjo S,.dr,.SpPD.,.KGEH beserta sejawat lainnya, yang telah membantu pemeriksaan PHA di Laboratorium Unit Riset Biomedik RSU Mataram, saya ucapkan terima kasih .

\section{Daftar Pustaka}

1. Marshall B.J. Epidemiology of Helicobacter pylori in Western countries. Dalam: Hunt RH, Tytgat GNJ, penyunting. Helicobacter pylori. Basic Mechanism to Clinical Cure. Edisi ke-1. London: Kluwer Academic Pub, 1994. h. 75-80.

2. Suparyatmo JB. Soewignjo S, dan Mutaqin Z. Survei seroepidemiologik infeksi Helicobacter pylori di Surakarta. Makalah lengkap dari kumpulan Seminar Nasional Helikobakter Pilori dan Penyakit Gastroduodenal. Denpasar, Bali 25 Maret 1995. h. 96-7.

3. Forman D, Webb P. Geographical distribution and association with gastric cancer. Dalam: Northfield TC, Mendall M, Goggin PM, penyunting. Helicobacter py- lori infection. Edisi ke-1. London: Kluwer Academic Pub; 1993. h. 11-12.

4. Fauchere JL. Evaluation of the anti-Helicobacter pylori serum antibody respons. Dalam: Lee A, Megraud F, penyunting. Helicobacter pylori: Technic for diagnosis and basic research. London: WB Saunders Co; 1996. h. $50-1$

5. Covacci A. Rappuoli R. PCR amplification of gene sequnces from Helicobacter pylori strains. Dalam; Lee A, Megraud F, penyunting. Helicobacter pylori: Technik for diagnosis and basic research. London: WB Saunders Co; 1996. h. 94-120.

6. Harijono A. Perbandingan berbagai tes dalam diagnosis Helicobacter pylori pada penderita dispepsia di RSSA Malang dan prevalensi seroepidemiologi Helicobacter pylori di Malang. Dalam: Kumpulan Seminar Nasional Helikobakter pilori dan Penyakit Gastroduodenal. Bali, 25 Maret, 1995. h. 111

7. Kandera I.W. Proporsi infeksi Helicobacter pylori pada anak-anak SD Dauh Puri Kodya Denpasar. Dalam: Soewignjo S, Mulyadi K, Kandera.W, Winata S, Purwadi G.N, 1995. Seminar Nasional Helikobakter Pilori dan penyakit Gastroduodenal. Kelompok Studi Helikobakter pilori. Fakultas Kedokteran Unud, Bali: 25 Maret, 1995. h. 89-92.

8. Rothenbacher D, Bode G, berg G, Knayer U, Gonser T, Adler G, Brenner H. Helicobacter among preschool children and their parents. Evidence of parent-child transmission. J Infect Dis 1999; 179:398-401

9. Roekiandari M, Idayati A, Wasito E.B. Daya hidup Helicobacter pylori pada air kran PAM yang ditambah urea, air limbah domestik dan air sumur. JBP. 1999;1: 48-51

10. Gold B.D. New approach to Helicobacter pylori infection in children. Atlanta Current Science Inc. Ped Gastr, 2003; 235-47

11. Soebagyo. Peran ibu dan keluarga sebagai faktor risiko kejadian infeksi kuman Helicobacter pylori pada anak umur 0-5 tahun di Surakarta. Disertasi Universitas Airlangga, 2004.

12. Goodman S. Historical and microbiological prespectives. Dalam: Northfield.T.C, Mendal and Goggin P.M. Helicobacter pylori infection, epidemiology and management. London: Kluwer Academic Publisher; 1993. h. $1-9$.

13. Luzza F, Mancuso M, Imeneo M, Contaldo A, Giancotti L. Evidence favouring the gastro-oral route in the transmission of Helicobacter pylori infection in children. Eur J Gastroenterol \& Hepatol 2000; 12:623-627. 